\title{
Surveilans Influenza pada Pasien Rawat Jalan
}

\author{
Putu Siadi Purniti, * Ida Bagus Subanada, ${ }^{*}$ Ida Sri Iswari** \\ *Bagian Ilmu Kesehatan Anak FK UNUD/RSUP Sanglah Denpasar \\ **Bagian Mikrobiologi FK UNUD/RSUP Sanglah Denpasar
}

\begin{abstract}
Latar belakang. Influenza merupakan infeksi yang sering terjadi dan memberikan dampak yang besar pada kelompok usia anak. Informasi mengenai tingkat kunjungan pasien seasonal influenza diperlukan untuk menilai besarnya dampak yang ditimbulkan penyakit influenza Rapid influenza test dapat membantu diagnosis dan penanganan pasien yang datang dengan manifestasi klinis seasonal influenza.

Tujuan. Untuk mengetahui tingkat kunjungan pasien dengan seasonal influenza dan nilai diagnostik pemeriksaan rapid influenza test.

Metode. Surveilans seasonal influenza dilaksanakan di Poliklinik Rawat Jalan Bagian//SMF Ilmu Kesehatan Anak RSUP Sanglah Denpasar Bali selama periode 1 Januari 2005 sampai 31 Desember 2006. Pasien usia 1 bulan sampai dengan 12 tahun dengan manifestasi klinis influenza like illness berdasarkan kriteria WHO diikutsertakan dalam penelitian. Pada subyek penelitian dilakukan apusan hidung untuk pemeriksaan rapid inAuenza dan apusan tenggorok untuk pemeriksaan reverse transcriptase polymerase chain reaction (RT-PCR). Hasil. Didapatkan prevalensi seasonal influenza pada anak di RSUP Sanglah Denpasar Bali 16,8\%. Dua puncak kejadian terjadi pada periode bulan Januari sampai April dan September sampai Desember. Pemeriksaan rapid influenza memiliki sensitivitas 12,87\% (IK 95\%: 12,54-12,89\%), spesifisitas 99,6\% (IK 95\%: 99,59-99,61\%), nilai duga positif 86,67\% (IK 95\%: 86,47-86,94\%), nilai duga negatif 84,98\% (IK 95\%: 82,18-87,78\%), rasio kemungkinan positif 32,18\% (IK 95\%: 28,45-35,91\%), dan rasio kemungkinan negatif 0,88\% (IK 95\%:62,1-113,8\%).

Kesimpulan. Prevalensi seasonal influenza pada penderita rawat jalan di Poliklinik anak RSUP Sanglah Denpasar Bali 16,8\%. Dua puncak kejadian terjadi pada periode bulan Januari-April dan SeptemberDesember. Pemeriksaan rapid infuenza memiliki sensitivitas yang rendah tetapi spesifisitas dan nilai duga positif yang tinggi. Sari Pediatri 2010;12(4):278-82.
\end{abstract}

Kata kunci: surveilans, seasonal influenza, rapid influenza test

$\mathrm{I}$ nfeksi respiratori akut (IRA) menyebabkan angka kematian dan kesakitan yang bermakna pada anak. ${ }^{1,2}$ Influenza merupakan penyakit respiratori yang penting dan terjadi secara di

\footnotetext{
Alamat korespondensi:

Dr. Ida Bagus Subanada, Sp.A(K). Bag.SMF Ilmu Kesehatan Anak FK UNUD/RSUP, Sanglah. Jln P. Nias Denpasar Bali. Telepon/Fax: 0361244038. E-mail: putu_siadi@yahoo.com
}

seluruh dunia., ${ }^{3,4}$ Pada dua dekade terakhir jumlah infeksi respiratori yang menjalani rawat inap meningkat dan 20-50 juta kasus disebabkan oleh influenza di Amerika Serikat. ${ }^{4}$ Penelitian-penelitian komunitas di Amerika Serikat yang menghitung beban dan beratnya infeksi influenza mendapatkan bahwa influenza menyebabkan peningkatan kunjungan pasien rawat jalan 24\% sampai 35\%, angka rawat inap 18\% sampai $20 \%$, dan penggunaan antibiotik pada anak selama 
musim influenza $14 \%$ sampai $20 \% .^{5}$ Virus influenza memiliki dampak yang besar pada anak terutama pada anak golongan usia sekolah karena memiliki angka infeksi yang tertinggi. ${ }^{5,6}$

Pandemi influenza pada tahun 1918 (Spanish flu), tahun 1957 (Asian flu), tahun 1968 (Hongkong flu), dan tahun 2009 (Swine flu/H1N1 2009), disebabkan oleh hasil reassortment beberapa strain virus Influenza. Kejadian tersebut mengingatkan kita akan pentingnya surveilans dari virus influenza untuk persiapan menghadapi kemungkinan terjadinya pandemi berikutnya. ${ }^{3}$ Surveilans influenza bertujuan untuk mengevaluasi angka kesakitan dan kematian yang ditimbulkan akibat influenza, mengidentifikasi waktu kejadian penyakit, dan karakteristik isolat virus yang berguna dalam pembuatan vaksin. ${ }^{3}$ Informasi mengenai tingkat kunjungan pasien rawat jalan yang terkait influenza diperlukan untuk mengevaluasi akibat yang mungkin ditimbulkan di bidang pelayanan kesehatan dan analisis biaya yang diperlukan dalam tata laksana penyakit tersebut. ${ }^{7}$

Biakan virus merupakan baku emas untuk diagnosis influenza, namun kurangnya fasilitas untuk memperoleh hasil membuat biakan tidak praktis secara klinis. Reverse-transcription polymerase chain reaction (RT-PCR) lebih sensitif daripada biakan virus standar dalam deteksi virus influenza, namun RT-PCR tidak tersedia secara luas dalam penggunaan klinik. ${ }^{8}$ Sebagai alternatif, influenza rapid antigen detection (rapid influenza test) merupakan tes yang relatif murah, dan dapat memberikan identifikasi infeksi influenza dengan cepat dan sangat berguna dalam pengambilan keputusan klinis, meskipun tes ini interpretasinya tergantung pada prevalensi influenza. ${ }^{8}$ Aspek positif lain yang didapat dari pemeriksaan rapid influenza test, adanya kesempatan penggunaan terapi antiviral lebih dini dalam membatasi transmisi virus, menghindari pemberian antibiotik yang tidak perlu, mengurangi lama rawat di rumah sakit, dan menyediakan waktu yang cukup untuk edukasi kepada orangtua anak mengenai pentingnya vaksin influenza. Penelitian ini bertujuan untuk mengetahui tingkat kunjungan pasien seasonal influenza, dan mengetahui nilai diagnostik rapid influenza test.

\section{Metode}

Surveilans terhadap semua pasien telah dilakukan di
Poliklinik Rawat Jalan di Bagian/SMF Ilmu Kesehatan Anak RSUP Sanglah Denpasar Bali antara tanggal 1 Januari 2005 sampai 31 Desember 2006. Usia pasien antara 1 bulan sampai dengan 12 tahun, menunjukkan manifestasi klinis menyerupai penyakit influenza (influenza like illness / ILI) berdasarkan kriteria WHO, dan orangtua/wali bersedia menandatangani informed consent. Kriteria ILI adalah anak mengalami awitan demam mendadak $>38^{\circ} \mathrm{C}$ dan batuk atau nyeri menelan, setelah kemungkinan diagnosis penyakit lain disingkirkan. Pada subjek penelitian dilakukan wawancara dan pemeriksaan klinis yang dicatat pada kuesioner penelitian, dan kemudian dilakukan pengambilan usapan hidung untuk rapid influenza test, dan usapan tenggorok untuk reverse transcriptase polymerase chain reaction (RT-PCR) yang dilakukan di laboratorium NAMRU 2 di Jakarta. Penelitian ini telah disetujui oleh Komite Etik Penelitian FK Universitas Udayana/RSUP Sanglah.

Data antara lain karakteristik subjek, hasil pemeriksaan rapid influenza test, dan RT-PCR. Data yang didapat disajikan secara deskriptif. Disamping itu dilakukan juga perhitungan sensitifitas, spesifisitas, nilai duga positif, nilai duga negatif, rasio kemungkinan positif, rasio kemungkinan negatif, prevalensi dan posttest probability dari rapid influenza test dengan baku emas RT-PCR.

\section{Hasil}

\section{Data surveilans}

Selama periode 1 Januari 2005 sampai dengan 31 Desember 2006, kami mendapatkan 601 subjek. Karakteristik subjek tertera pada Tabel 1.

Subjek terdiri dari 59\% laki-laki. Subjek penelitian yang positif pada pemeriksaan influenza RT-PCR 101 anak sehingga didapatkan prevalensi seasonal influenza pada anak di RSUP Sanglah Denpasar Bali 16,8\%.

Pada Gambar 1 tampak bahwa prevalensi seasonal influenza selama periode penelitian mengalami dua puncak kejadian yaitu pada bulan Oktober sampai Desember tahun 2005 dan bulan Februari sampai bulan April tahun 2006. Distribusi seasonal influenza berdasarkan usia tertera pada Gambar 2. Rentang usia tertinggi untuk kejadian seasonal influenza adalah pada usia 2 sampai 5 tahun.

Rapid influenza test positif untuk influenza A 
Tabel 1. Karakteristik subyek penelitian

\begin{tabular}{lcc}
\hline Variabel & $\begin{array}{c}\text { Jumlah } \\
(\mathrm{n}=601)\end{array}$ & Persentase (\%) \\
\hline Laki-laki & 356 & 59,2 \\
Kelompok usia (tahun) & & \\
$\quad$ • $<2$ & 263 & 43,8 \\
- 2-5 & 204 & 33,9 \\
- 5-7 & 80 & 13,3 \\
- 7-12 & 53 & 8,8 \\
Rapid influenza test & & \\
$\quad$ - Influenza A & 10 & 1,7 \\
- Influenza B & 63 & 10,5 \\
RT- PCR : & & \\
$\quad$ - Influenza A & 38 & 6,3 \\
- Influenza B & 63 & 10,5 \\
Serotipe & & \\
$\quad$ - Influenza A H1N1 & 10 & 1,7 \\
- Influenza A H3N1 & 1 & 0,2 \\
$\quad$ - Influenza A H3N2 & 26 & 4,3 \\
- Influenza B & 63 & 10,5 \\
\hline
\end{tabular}

$1,7 \%$ dan influenza B 10,5\%. Influenza A yang terkonfirmasi positif dengan RT-PCR 6,3\%, dan yang positif untuk influenza B $10,5 \%$. Pemeriksaan serotipe influenza $\mathrm{H} 1 \mathrm{~N} 1$ 1,7\%, serotype $\mathrm{H} 3 \mathrm{~N} 1$ 0,2\%, serotipe H3N2 4,3\%, dan influenza B 10,5\%. Prevalensi seasonal influenza berdasarkan serotipe tertera pada Gambar 3. Pada Tabel 2 tampak bahwa rapid influenza test memiliki sensitivitas 12,87\% (IK 95\%; 12,54-12,89\%), spesifisitas 99.6\% (IK 95\%; 99,59-99,61\%), rasio kemungkinan positif 32,18\% (IK 95\%; 28,45-35,91\%), rasio kemungkinan negatif 0,88\% (IK 95\%: 62,1-113,8\%) nilai duga positif $86,67 \%$ (IK 95\%; 86,47-86,94\%), nilai duga negatif $84,98 \%$ (IK 95\%; 82,18-87,78\%), dan prevalensi $16,8 \%$ (IK 95\%; 13,9-19,7\%).

Tabel 2. Akurasi rapid influenza test

\begin{tabular}{lcccc}
\hline & & \multicolumn{2}{c}{ RT-PCR } \\
& & \multicolumn{2}{c}{ Influenza } & \\
\cline { 3 - 4 } & & Positif & Negatif & \\
\hline Rapid influenza & Positif & 13 & 2 & 15 \\
test & Negatif & 88 & 498 & 586 \\
\cline { 2 - 5 } & Total & 101 & 500 & 601 \\
\hline
\end{tabular}

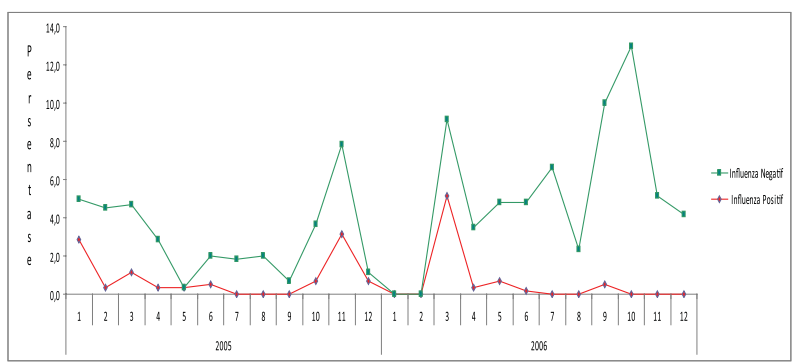

Gambar 1. Prevalensi influenza musiman dari bulan Januari 2005 - Desember 2006

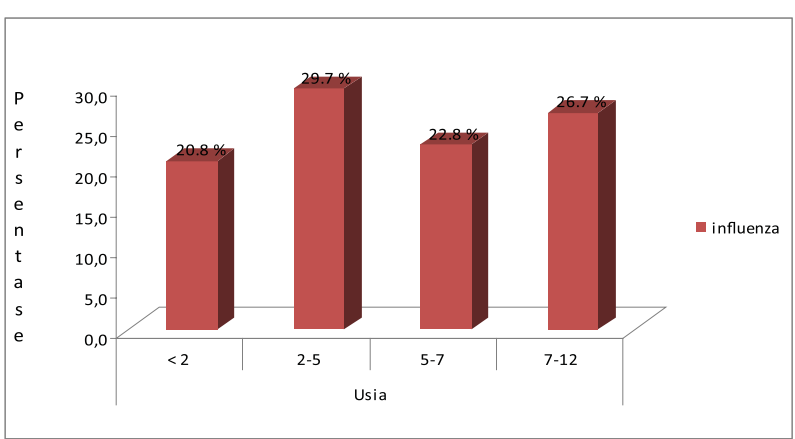

Gambar 2. Distribusi seasonal influenza berdasarkan usia

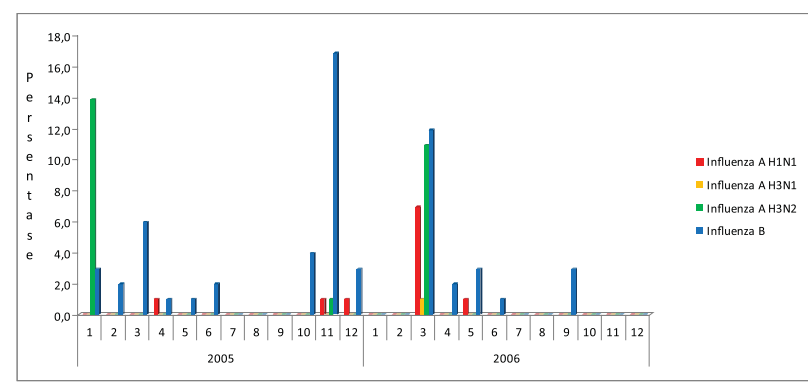

Gambar 3. Prevalensi influenza berdasarkan serotipe

\section{Pembahasan}

Virus influenza tipe A mempunyai antigen permukaan dua glikoprotein yaitu antigen hemaglutinin (HA) dan antigen neurominidase (NA). Jika kedua glikoprotein dikombinasikan maka terdapat 135 subtipe virus (strain), namun hanya tiga subtipe HA yang menyerang manusia yaitu $\mathrm{H} 1, \mathrm{H} 2$, dan $\mathrm{H} 3$ sedangkan dari dua subtipe NA yang menyerang manusia yaitu N1 dan $\mathrm{N} 2$. Subtipe baru virus influenza dapat terjadi akibat mutasi yang disebut dengan antigenic drift dan akibat reassortment disebut antigenic shift. Antigenic drift terjadi setiap dua sampai tiga tahun sekali, virus baru 
yang terbentuk dapat menyebabkan epidemi. Antigenic shift yaitu terjadi reassortment dari dua virus influenza A yang berasal dari dua spesies yang berbeda membentuk virus dengan antigen baru yang dapat menyebabkan pandemi. Virus Influenza sangat mudah ditularkan dari orang ke orang melalui percik renik yang dikeluarkan oleh orang yang terinfeksi saat batuk atau bersin. Transmisi dapat juga terjadi melalui kontak langsung dari kulit ke kulit yang mengandung sekret respiratori yang terinfeksi kemudian menyentuh mata hidung atau mulut. Virus influenza masuk melalui hidung atau mulut akan menyebabkan infeksi traktus respiratori yaitu hidung, tenggorokan, dan bronkus. Masa inkubasi secara pasti tidak jelas diketahui, diperkirakan antara 1-7 hari, terbanyak 1-4 hari, dan infeksi pada umumnya berlangsung kurang dari satu minggu. Orang yang terinfeksi dapat menularkan kepada orang lain sehari sebelum gejalanya muncul sampai tujuh hari kemudian. Penyebaran dari orang ke orang terjadi sangat cepat, terutama di tempat pemukiman yang padat. Virus dapat bertahan lama di udara luar pada saat udara dingin dan kering, oleh karena itu epidemi sering terjadi pada saat musim dingin. ${ }^{6}$

Data surveilans penelitian kami mendapatkan prevalensi seasonal influenza pada pasien rawat jalan $16,8 \%$. Penelitian ini serupa dengan penelitian Zaman $\mathrm{dkk}^{9}$ di Bangladesh tahun 2007-2008 melaporkan prevalensi influenza $10 \%$ pada pasien rawat jalan dan rawat inap, sedangkan Ramamurty $\mathrm{dkk}^{10}$ di India tahun 2002 melaporkan prevalensi influenza 12,5\% pada pasien rawat jalan. Di negara dengan empat musim, influenza banyak menginfeksi manusia pada musim dingin, ${ }^{11,12}$ sedangkan di negara-negara yang berada di daerah tropis, influenza banyak terdeteksi pada musim hujan. ${ }^{13}$ Penelitian di Bali ini mendapatkan influenza meningkat pada bulan Oktober sampai Desember yaitu pada awal musim hujan dan bulan Februari sampai April merupakan peralihan musim hujan ke musim kemarau.

Manifestasi klinis bervariasi mulai dari selflimited sampai terjadi gejala yang berat termasuk gagal napas dan kematian. Manifestasi klinis dapat berupa demam, nyeri kepala, batuk, nyeri menelan, mialgia, menggigil, dan lemah, kadang-kadang disertai diare dan muntah. Kelompok umur yang mempunyai risiko tinggi yaitu umur balita terutama pada umur di bawah dua tahun, orang tua berusia di atas 65 tahun, wanita hamil, anak dengan status gizi buruk, dan orang yang memiliki penyakit kronik seperti asma, penyakit ginjal kronik, hepar kronik, dan diabetes melitus.

Pada penelitian kami influenza positif paling banyak pada kolompok umur 2-5 tahun (29,7\%), dan umur 7-12 tahun (26,7\%). Berbeda dengan penelitian di Bangladesh influenza terbanyak pada kelompok umur 11-15 tahun. Hal ini kemungkinan karena Zaman RU di Banglades meneliti semua umur pasien rawat jalan dan rawat inap, sedangkan pada penelitian kami hanya pada pasien anak rawat jalan. Di Eropa tahun 2006-2007 diisolasi virus influenza A H1N1, H3N2, dan influenza B. ${ }^{11}$ Di India pada tahun 2002 diisolasi influenza A H3N2 dan influenza $B^{10}$ sedangkan di Bangladesh tahun 2007-2008 diisolasi influenza B, influenza A H1 dan H3. ${ }^{9}$ Penelitian kami dilaksanakan pada tahun 2005-2006 diisolasi paling banyak influenza B (10,5\%), influenza A H3N2 (4,3\%), H1N1 (1,7\%), dan H3N1 (0,2\%).

Influenza berhubungan dengan tingginya angka kesakitan dan bahkan kematian tetapi influenza dapat dicegah dengan vaksinasi dan dapat diobati dengan pemberian antiviral. Oleh karena itu diperlukannya alat diagnostik yang cepat. Rapid diagnostic test dapat dilakukan dengan cepat, lebih awal minimal 48 jam setelah gejala timbul sehingga dapat membantu dalam pemberian antiviral dan mengurangi penggunaan antibiotik yang tidak sesuai. ${ }^{13}$ Penelitian kami mendapatkan hasil pemeriksaan rapid influenza test tidak sensitif tetapi sangat spesifik sehingga bila hasil test positif maka memastikan bahwa orang tersebut menderita influenza. Prevalensi seasonal influenza 16,8\% (IK 95\%: 13,9-19,7\%). Sesuai dengan rekomendasi WHO yang menganjurkan pada daerah dengan prevalensi influenza rendah, apabila hasil rapid influenza test positif, harus dikonfirmasi dengan pemeriksaan immunofluorescence assay (IFA), kultur virus atau RT-PCR. Tetapi apabila dalam keadaan terjadi prevalensi influenza tinggi (outbreak) rapid test dapat dipergunakan dalam menentukan diagnosis dan sebagai pedoman pemberian pengobatan. ${ }^{13}$

Disimpulkan terjadi dua puncak kejadian seasonal influenza pada periode bulan Januari-April dan September - Desember. Prevalensi seasonal influenza pada anak di RSUP Sanglah Denpasar Bali sebesar $16,8 \%$ yang terdiri dari influenza $B$ terdeteksi $10,5 \%$, Influenza A H3N2 4,3\%, H1N1 1,7\% dan H3N1 $0,2 \%$. Rapid influenza test memiliki sensitivitas yang rendah tetapi dengan spesifisitas dan nilai duga positif yang tinggi, sehingga pemeriksaan RT-PCR atau isolasi virus masih diperlukan untuk diagnostik. 


\section{Daftar pustaka}

1. World Health Organization. The United Nation Declaration 2000: millenium developmental goals (MDS'S). New York: World Health Organization; 2008.

2. Bonner AB, Monroe KW, Talley LI, Klasner AE, Kimberlin DW. Impact of the rapid diagnosis of influenza on physician decision-making and patient management in the pediatric emergency department: results of a randomized, prospective, controlled trial. Pediatrics 2003;112:363-7.

3. Iwane MK, Edwards KM, Szilagyi PG, Walker FJ, Griffin MR, Weinberg GA, dkk. Population-based surveillance for hospitalizations associated with respiratory syncytial virus, influenza virus, and parainfluenza viruses among young children. Pediatrics 2004;113:1758-64.

4. Marco GD, Mangani S, Correra A, Caro SD, Tarallo L, Franciscis AD, dkk. Reduction of inappropriate hospital admissions of children with influenza-like illness through the implementation of specific guidelines: a case-controlled study. Pediatrics 2005;116:e506-11.

5. Ampofo K, Gesteland PH, Bender J, Mills M, Daly J, Samore M, dkk. Epidemiology, complications, and cost of hospitalization in children with laboratory-confirmed influenza infection. Pediatrics 2006;118:2409-17.

6. Poehling KA, Griffin MR, Dittus RS, Tang YW, Holland K, Li H, dkk. Bedside diagnosis of influenza virus infections in hospitalized children. Pediatrics
2002;110:83-8.

7. O’Brien MA, Uyeki TM, Shay DK, Thompson WW, Kleinman K, McAdam A, dkk. Incidence of outpatient visits and hospitalizations related to influenza in infants and young children. Pediatrics 2004;113:585-93.

8. Grijalva CG, Poehling KA, Edwards KM, Weinberg GA, Staat MA, Iwane MK, dkk. Accuracy and interpretation of rapid influenza tests in children. Pediatrics 2007;119:e611.

9. Zaman RU, Alamgir ASM, Rahman M, AzzizBaumgartner E, Gurley ES, Sharker MAY, dkk. Influenza in outpatient ILI case-patients in national hospital-based surveillance, Bangladesh, 2007-2008. PLoS One 2009; 4:e8452.

10. Ramamurty N, Pillai LC, Gunasekaran P, Elango V, Mohana, Priya P, dkk. Influenza activity among the paediatric age group in Chennai. Indian J Med Res 2005;121:776-9.

11. Arkema MS, Meijer A, Meerhoff TJ, Van der Velden J, Paget WJ. Epidemiological and virological assessment of influenza activity in Europe, during the 2006-2007 winter. Euro surveillance 2008;13:1-7.

12. World Health Organization. WHO influenza centre 2005: recommendation on the use of rapid testing for influenza diagnosis. New York: World Health Organization; 2005.

13. Rao BL, Banerjee K. Influenza surveillance in Pune, India, 1978-90. Bull World Health Organ 1993;71:17781 . 